\title{
Nelayan Lonrae Kabupaten Bone 1975-2017
}

\author{
Dian Artifah Arfah,Najamuddin,H. Rasyid Ridha. \\ Prodi Pendidikan Sejarah Fakultas Ilmu Sosial Universitas Negeri Makassar \\ dianartifah1234@gmail.com
}

\begin{abstract}
Abstrak
Penelitian ini bertujuan untuk mengetahui latar belakang kehidupan nelayan di Kelurahan Lonrae, perkembangan dari segi alat tangkap dan perkembangan armada perahu yang digunakan serta dampak yang timbul dalam bidang sosial ekonomi dan budaya pada masyarakat Nelayan di Kelurahan Lonrae. Prosedur penelitian ini mengacu pada beberapa tahapan dalam metode penelitian sejarah yang terdiri dari Heuristik (pengumpulan data) dengan wawancara serta sumber tertulis), kritik, interpretasi (penafsiran) dan terakhir adalah historiografi (penulisan sejarah). Hasil penelitian ini menunjukkan bahwa nelayan di Kelurahan Lonrae mengalami perkembangan baik dari pola penangkapan ikan, segi alat tangkap yang digunakan. Selain Perkembangan pada alat tangkap juga terjadi pada perkembangan perahu yang digunakan oleh masyarakat nelayan di Kelurahan Lonrae selanjutnya perkembangan pada masyarakat nelayan di Kelurahan Lonrae seperti usaha rumah tangga masyarakat nelayan di Kelurahan Lonrae seperti pedagang Ikan Asap yang digeluti oleh kalangan perempuan yang memberikan keuntungan lumayan sebesar Rp.500.000,- perminggu yang memberikan dampak terhadap sektor perekonomian. Berdasarkan hasil penelitian ini maka dapat disimpulkan bahwa perkembangan dari segi alat tangkap dan perahu yang dipergunakan merangsang munculnya pelaku ekonomi yang turut berpartisipasi serta memanfaatkan peluang untuk meningkatkan taraf kehidupan masyarakat nelayan terutama dalam bidang ekonomi, hal ini menunjukkan bahwa keadaan ekonomi turut mempengaruhi status sosial dalam masyarakat.
\end{abstract}

Kata Kunci: Nelayan, Kelurahan Lonrae

\begin{abstract}
This study aims to determine the background of the life of fishermen in Lonrae Kelurahan, developments in terms of fishing gear and the development of the fleet of boats used and the impacts arising in the socio-economic and cultural fields of the fishing communities in Lonrae Kelurahan. This research procedure refers to several stages in the historical research method consisting of Heuristics (data collection) with interviews and written sources), criticism, interpretation (interpretation) and finally historiography (history writing). The results of this study indicate that fishermen in the Lonrae Village experienced a good development in terms of fishing patterns, in terms of fishing gear used. In addition to developments in fishing gear also occurred in the development of boats used by the Lonrae fishing community and further developments in the fishing communities in Lonrae Kelurahan such as household businesses in Lonrae Kelurahan such as Smoked Fish traders among women gived advantage is Rp.500.00,who have an impact on the economic sector. Based on the results of this study it can be concluded that the development in terms of fishing gear and boats used stimulates the emergence of economic actors who participate and take advantage of opportunities to improve
\end{abstract}


the lives of fishing communities, especially in the economic field, this shows that economic conditions also influence social status in society

\section{Keywords: Fishermen, Kelurahan Lonrae}

\section{A. Pendahuluan}

Salah satu pulau yang penduduknya beraktivitas dibidang maritim di Kawasan Indonesia bagian timur ialah pulau Sulawesi khususnya Sulawesi Selatan. Letak Sulawesi Selatan yang dikelilingi oleh wilayah lautan sehingga masyarakatnya banyak memilih profesi sebagai nelayan. Kegiatan kehidupan masyarakat sehari-hari, tampak telah akrab dengan suasana laut dan melakukan kegiatan penangkapan ikan baik di wilayah pesisir pantai maupun di lepas pantai. karena laut merupakan tempat untuk mencari nafkah bagi seorang nelayan dan merupakan aktivitas yang biasa mereka lakukan. (M. R. Alimuddin 2004)

Adapun salah satu daerah di Sulawesi Selatan yang masyarakatnya berperan di bidang penangkapan ikan adalah Kabupaten Bone. Salah satu Kelurahan yang ada di Kabupaten Bone yang berada di bagian utara yang mayoritas penduduknya bekerja sebagai nelayan adalah Kelurahan Lonrae. Hal ini disebabkan karena wilayah ini berada di bibir pantai barat sehingga mewarnai corak kehidupan masyarakat sebagai nelayan, karena ada tiga faktor yaitu tanah tandus dan sempit, memiliki garis pantai yang panjang, dan tidak punya pekerjaan selain melaut sehingga memanfaatkan sumber daya laut sebagai mata pencaharian mereka, kemampuan ini yang diwariskan turun temurun oleh pendahulu mereka sampai sekarang melalui proses interaksi sosial.

Pada 1960-an penangkapan ikan khususnya di Sulawesi Selatan masih sederhana dan terbilang terbatas sama halnya juga dengan nelayan di Kelurahan Lonrae masih terbatas. Pada periode ini penangkapan ikan masih terbilang terbatas karena alat tangkap masih sangat sederhana dan sehingga jarak area penangkapan dari wilayah pesisir pantai masih dekat. Nelayan menggunakan perahu yang ukurannya kecil yang digerakkan dengan layar dan alat tangkap berupa pancing, bubu, dan jaring yang masih sederhana. Hal ini di sebabkan karena usaha penangkapan ikan masih bersifat individual serta fasilitas pendukung belum memadai. Mereka juga sangat bergantung pada arah angin karena layar sebagai tenaga penggerak yang dahulu di gunakan beberapa abad silam dalam mengarungi samudera tanpa mesin (A. R. Hamid 2010).

Kemudian pada tahun 1975 Nelayan di Kelurahan Lonrae mulai adanya pengembangan teknologi modern dalam proses sistem penangkapan ikan dilaut sehingga memberikan hasil yang lebih banyak dibandingkan dengan periode sebelumnya bahkan telah mempunyai kemampuan untuk melipat gandakan hasil penangkapannya.

Seiring dengan perkembangan zaman menuntut manusia dalam pemenuhan kebutuhan yang semakin banyak maka tentu dia harus pula mengikuti perkembangan zaman, mereka harus mampu menyesuaikan diri dengan keadaan. Kebutuhan yang semakin bertambah mendorong masyarakat sekitar untuk meningkatkan hasil tangkapan dengan memanfaatkan kemajuan dari teknologi. Di indonesia sendiri secara umum nelayan dapat dikategorikan dalam dua kelompok, kelompok pertama adalah nelayan kaya dan kaya sekali di satu pihak, dan kelompok ekonomi sedang, miskin, miskin sekali. (Mubyarto 1984)

Pada dasarnya penelitian mengenai nelayan di suatu daerah telah banyak ditulis baik dalam bentuk buku, skripsi, jurnal. Seperti halnya buku yang ditulis oleh “Ketika Lautku Tak Berikan Lag” yang 
ditulis oleh Ahmadin tahun 2009 yang menggambarkan tentang nelayan di Kampung Padang yang menghuni daerah Pantai Barat Selayar.

Adapun karya ilmiah dalam bentuk jurnal yang ditulis oleh Haerianty Reski Sani tahun 2005 dengan judul Penetrasi Nelayan Tradisional Panaikang 1955-1970. Jurnal ini membahas tentang strategi nelayan dalam mempertahankan kelangsungan hidup. Pola penangkapan ikan nelayan tradisional di Desa Panaikang menggunakan alat tangkap yang sederhana berupa payang (panja) sehingga dijuluki sebagai nelayan pa'panja. Perahu yang digunakan berukuran panjang dan memuat hingga 12 orang. Wilayah operasional awalnya dekat dari pesisir pantai namun lambat laun merambah jauh ke wilayah tttanjung pandang dan Bangka. Nelayan di Desa Panaikang menjadikan kegiatan penangkapan ikan di laut sebagai pekerjaan pokok untuk menghidupi keluarganya.

Melihat kehidupan nelayan di Kelurahan Lonrae dari tahun 1975-2017, meskipun telah menghadapi beberapa kendala namun mereka tetap menggeluti pekerjaan sebagai nelayan. Oleh karena itu, penulis tertarik untuk mengkaji tentang Nelayan di Kelurahan Lonrae (1975-2017). Batasan temporal yang dikaji pada jurnal ini yakni 1975-2017. dimana tahun 1975 merupakan langkah awal terjadinya pembaharuan masyarakat pesisir yang kemudian berkembang sampai sekarang dan pada tahun 2017 nelayan di Kelurahan Lonrae yang telah banyak mengalihkan usaha penangkapan ikan pada skala yang lebih besar. Batasan spasial jurnal ini di Kelurahan Lonrae kecamatan Tanete Riattang Timur Kabupaten Bone. Batasan Tematik kajian tulisan ini yakni Sejarah maritim.

\section{B. Metode Penelitian}

Dalam melakukan suatu penelitian, banyak cara yang dilakukan oleh peneliti baik berdasarkan proses, prosedur, maupun prinsip yang dianut. Dengan demikian, berdasarkan atas tujuan dan kategori data yang dibutuhkan, menyebabkan terjadinya perbedaan metode yang diterapkan dalam kegiatan penelitian. Beberapa metode yang umum digunakan dalam penelitian, salah satunya adalah penelitian sejarah (Ahmadin, 2013)

Metode penelitian yang digunakan ialah kualitatif. Metode ini digunakan dalam ilmu sejarah dan ilmu sosial lainnya dengan tujuan untuk menemukan suatu hal yang unik dan mampu mengungkapkan peristiwa yang terjadi di masa lampau. Penelitian ini diarahkan untuk meneliti, mengungkapkan serta menjelaskan sejarah latar belakang kehidupan masyarakat nelayan di Kelurahan Lonrae, perkembangan kehidupan masyarakat nelayan di Kelurahan Lonrae serta dampak kehidupan masyarakat nelayan di Kelurahan Lonrae. Penelitian ini termasuk dalam kajian sejarah maritim.

Dalam suatu penulisan karya ilmiah, terdapat cara yang digunakan untuk menyusun karya ilmiah tersebut. Adapun tahap-tahap yang dilakukan dalam penulisan karya ini melalui empat metode penelitian sejarah diantaranya adalah :

1. Heuristik

Heuristik atau pengumpulan sumber adalah tahap awal dalam metode historis yang diarahkan pada kegiatan pengumpulan sumber primer dan sekunder yang berkaitan dengan masalah atau objek yang diteliti. Sumber primer merupakan sumber utama dari topik penelitian, misalnya arsip, dokumen, sumber lisan, dan sumber benda. Adapun sumber sekunder merupakan sumber pelengkap, seperti buku, jurnal, dan laporan hasil penelitian (skripsi). (M. D. Madjid, Ilmu Sejarah Sebuah Pengantar 2014)

Volume 6 No.2 April-Juni 2019, 65-77 |67 
Kegiatan pengumpulan data atau heuristik pada penelitian ini didasarkan pada dua cara yaitu penelitian lapangan dan penelitian pustaka. Dalam melakukan pengumpulan sumber, peneliti menempuh dua cara yaitu penelitian lapangan dan penelitian pustaka

\section{a. Penelitian Pustaka}

Penelitian pustaka dilakukan untuk menunjang penelitian lapangan. Penelitan pustaka dapat dilakukan dengan mengumpulkan sumber berupa buku-buku, dokumen pemerintah setempat, hasil penelitian maupun artikel ilmiah yang berkaitan dengan kehidupan masyarakat nelayan. Adapun tempat untuk mendapatkan sumber tersebut diperoleh dari perpustakaan wilayah provinsi Sulawesi Selatan, perpustakaan jurusan pendidikan sejarah UNM, Badan Pusat Statistik Kabupaten Bone, perpustakaan umum Universitas Negeri Makassar, dan Dinas Kelautan dan Perikanan Kabupaten Bone. Kedua cara tersebut dilakukan untuk memperoleh sumber yang terbagi menjadi dua yaitu sumber sejarah primer dan sumber sejarah sekunder.

\section{b. Penelitian Lapangan \\ 1) Observasi}

Observasi adalah pengamatan secara langsung terhadap objek yang telah diteliti atau terhadap lokasi penelitian. Metode observasi yang peneliti maksud adalah mengadakan pengamatan dan penginderaan langsung terhadap masyarakat atau obyek penelitian. Dalam hal ini peneliti telah melakukan observasi pada tempat peneliti melakukan penelitian yaitu di Kelurahan Lonrae yang terkait dengan kehidupan masyarakat nelayan di Kelurahan Lonrae.

\section{2) Wawancara}

Peneliti dalam hal ini melakukan wawancara terhadap orang yang dianggap berkompeten dalam objek yang diteliti ini. wawancara dilakukan dengan melakukan tanya jawab dengan beberapa informan yaitu nelayan di Kelurahan Lonrae, masyarakat nelayan di Kelurahan Lonrae, H. Darwis sebagai Pinggawa Lompo, H. Side sebagai Pinggawa Lopi, dan Lukman sebagai Sawi yang terkait ataupun terlibat dengan masalah yang yang diteliti sehingga dapat diperoleh informasi atau data primer.

Hasil wawancara dapat direkam maupun dicatat untuk selanjutnya diperbaiki pada saat penyusunan laporan penelitian. Selain itu, peneliti juga menggunakan dokumentasi penelitian. Hal tersebut dilakukan agar data yang diperoleh peneliti sifatnya objektif dan dapat dipertanggungjawabkan.

\section{Kritik Sumber}

Kemudian tahap yang dilakukan Setelah melakukan pengumpulan data maka langkah selanjutnya yang dilakukan adalah kritik sumber atau data-data yang ditemukan baik melalui penelitian lapangan maupun penelitiann pustaka. Tujuan dari kegiatan-kegiatan ini adalah bahwa setelah sejarawan berhasil mengumpulkan sumbersumber dalam penelitiannya, ia tidak akan menerima begitu saja apa yang tercantum dan tertulis pada sumber-sumber itu. Selanjutnya ia harus menyaringnya secara kritis agar terjaring fakta yang menjadi pilihannya. Langkah-langkah inilah yang disebut kritik sumber.

\section{Interpretasi}

Setelah faka-fakta disusun kemudian dilakukan interpretasi. Interpertasi sangat esensial dan krusial dalam metodologi sejarah. Fakta-fakta sejarah yang berhasil dikumpulkan belum banyak berceritra. fakta-fakta tersebut harus disusun dan digabungkan sehingga membentuk cerita peristiwa sejarah. Interpretasi atau penafsiran bersifat individual sehingga seringkali subyektif. Hal tersebut sangat dipengaruhi oleh latar belakang penulis sejarah itu sendiri (M. D. Madjid, Ilmu Sejarah Sebuah Pengantar 2014).

Volume 6 No.2 April-Juni 2019, 65-77 |68 


\section{Historiografi}

Historiografi merupakan tahap akhir dari penelitian sejarah, setelah melalui fase heuristik, kritik, dan interpretasi. Pada tahap terakhir inilah penulisan sejarah dilakukan. Pada tahap ini peneliti akan menuliskan peristiwa sejarah tersebut dalam sebuah tulisan yang dalam penulisan, pemaparan dan pelaporan menggunakan tata cara tertentu. Dimana dalam hal ini, penelitian yang peneliti lakukan adalah penelitian dengan kajian kepustakaan dan lapangan. Penulisan sejarah merupakan proses penjelasan dari semua kegiatan dalam proses penelitian sejarah. (M. D. Madjid, Ilmu Sejarah Sebuah Pengantar 2014).

\section{Tinjauan Umum Penelitian \\ 1. Kondisi Geografis}

Kelurahan Lonrae merupakan salah satu dari 8 kelurahan dalam wilayah administratif Kecamatan Tanete Riattang Timur Kabupaten Bone dengan luas wilayah 4,71 $\mathrm{Km}^{2}$. Jarak dari Ibu Kota Kabupaten ke Kelurahan adalah $15 \mathrm{~km}$. Secara administratif Kelurahan Lonrae terdiri dari 4 lingkungan yang berbatasan langsung dengan:
a. Sebelah Utara Berbatasan dengan
Kelurahan Toro
b. Sebelah Timur Berbatasan dengan
Teluk Bone
c. Sebelah Selatan Berbatasan dengan
Kelurahan Bajoe

d. Sebelah Barat Berbatasan dengan

Kelurahan Cellu

Secara umum kondisi geografis

Kelurahan Lonrae terdiri atas daratan dan pesisir pantai, yang merupakan bagian dari daratan rendah pantai yang membentang di sepanjang pantai Teluk bone. Kondisi demikian yang menjadikan wilayah Kelurahan Lonrae merupakan daerah penghasil ikan yang cukup besar yang mampu menyuplai kebutuhan masyarakat sampai di sekitar Kabupaten Bone sampai ke beberapa daerah lainnya. Hanya sedikit wilayahnya yang dapat dijadikan lahan pertanian. Itulah sebabnya masyarakat Lonrae utamanya laki-laki kebanyakan memilih profesi diluar pertanian yaitu sebagai nelayan dan pengusaha/pedagang.

Sesuai dengan data yang diperoleh, luas Kecamatan Tanete Riattang Timur $100,00 \mathrm{~km}^{2}$ dari total 8 wilayah Kelurahan. Ketinggian permukaan tanah berkisar antara 1,5 meter di atas permukaan laut sedangkan panjang garis pantainya $16 \mathrm{Km}^{2}$ secara keseluruhan wilayah pesisirnya, Curah hujan rata-rata pertahun $2000 \mathrm{~mm}$ dan suhu udara berkisar $24^{\circ}-30^{\circ} \mathrm{C}$. Berikut ini adalah tabel yang menggambarkan luas kelurahan yang ada di Kecamatan Tanete Riattang Timur:

\section{Tabel.1. Luas Wilayah Setiap Lingkungan di Kec. Tanete Riattang Timur}

\begin{tabular}{|l|l|c|}
\hline No. & \multicolumn{1}{|c|}{ Kelurahan } & Luas $\left(\mathbf{K m}^{2}\right)$ \\
\hline 1. & Kelurahan Bajoe & 11,42 \\
2. & Kelurahan Cellu & 12,56 \\
3. & Kelurahan Lonrae & 4,71 \\
4. & Kelurahan & 11,05 \\
& Tibojong & \\
5. & Kelurahan Panyula & 10,23 \\
6. & Kelurahan Toro & 8,39 \\
7. & Kelurahan Pallette & 13,71 \\
8. & Kelurahan & 27,95 \\
\multicolumn{3}{|c|}{ Waetuwo } \\
\hline
\end{tabular}

Masyarakat nelayan di Kelurahan Lonrae mengenal dua musim yang datang dan silih berganti dalam setahun, yakni angin musim barat dan angin musim timur. Musim Barat berlangsung antara bulan Oktober-Maret dan Musim Timur terjadi antara bulan April-September. Pada musim barat lautan menjadi tenang dan memungkinkan untuk melakukan

Volume 6 No.2 April-Juni 2019, 65-77 |69 
penangkapan ikan di laut bebas. Selama musim barat berlangsung nelayan berusaha semaksimal mungkin untuk melakukan penangkapan ikan sebanyak-banyaknya untuk memenuhi kebutuhan kehidupan sehari-harinya.

Jika musim barat sudah berganti musim timur maka cuaca tidak memungkinkan untuk melakukan aktivitas penangkapan ikan di laut karena ombak yang semakin besar mencapai ketinggian sampai lima meter dan angin dari arah timur bertiup kencan.

Tabel. 2Jumlah Curah Hujan di Kec. Tanete Riattang Timur 2017

\begin{tabular}{|c|c|c|}
\hline No. & Bulan & $\begin{array}{c}\text { Jumlah Curah } \\
\text { Hujan (mm) }\end{array}$ \\
\hline 1. & Januari & - \\
\hline 2. & Februari & - \\
\hline 3. & Maret & - \\
\hline 4. & April & 2000 \\
\hline 5. & Mei & 2000 \\
\hline 6. & Juni & 1.750 \\
\hline 7. & Juli & 2000 \\
\hline 8. & Agustus & 2000 \\
\hline 9. & September & 1.750 \\
\hline 10. & Oktober & - \\
\hline 11. & November & - \\
\hline 12. & Desember & -- \\
\hline \multicolumn{2}{|c|}{ Jumlah } & 11.250 \\
\hline
\end{tabular}

Sumber: Data Kantor Kecamatan Tanete Riattang Timur Tahun 2017

Berdasarkan tabel tersebut menunjukkan bahwa siklus iklim di wilayah
Kelurahan Lonrae terdapat dua musim yakni musim barat berlangsung antara bulan Oktober-Maret yang menandakan musim kemarau sedangkan musim timur berlangsung antara bulan April-September yang menandakan musim penghujan dengan jumlah rata-rata curah hujan sebanyak $2000 \mathrm{~mm}$ setiap bulan dan 11.250 mm pertahun

\section{Kondisi Demografis}

Demografi adalah mempelajari penduduk (suatu wilayah) terutama mengenai jumlah, stuktur (komposisi penduduk) dan perkembangannya (perubahannya). Penduduk merupakan indikator dalam perkembangan suatu kota karena perkembangan penduduk merupakan salah satu faktor pembangunan. Penduduk atau warga suatu negara atau daerah didefinisikan sebagai orang yang tinggal didaerah tersebut atau dengan kata lain orang yang secara hukum mempunyai surat resmi untuk tinggal didaerah tersebut. (Mantra 2000)

Berdasarkan data yang diperoleh pada Kelurahan Lonrae, jumlah penduduk Kelurahan Lonrae dari tahun 2013-2017 dapat dilihat dari Tabel 2.4 sebagai berikut:

Tabel 3. Jumlah penduduk Kelurahan Lonrae Tahun 2013- 2017

\begin{tabular}{|c|c|}
\hline Tahun & Jumlah Penduduk \\
\hline 2013 & 3030 \\
\hline 2014 & 3054 \\
\hline 2015 & 3069 \\
\hline 2016 & 3054 \\
\hline 2017 & 3108 \\
\hline
\end{tabular}

Sumber : Data BPS Kab. Bone Kec.

Tanete Riattang Timur Dalam Angka Tahun 2013-2017

Berdasarkan tabel tersebut menunjukkan bahwa jumlah penduduk di Kelurahan Lonrae tahun 2017 sebanyak 3108 Jiwa. Dalam lima tahun jumlah penduduk di Kelurahan Lonrae mengalami peningkatan dimana penurunan atau 
pertambahan jumlah penduduk ada beberapa faktor yang mempengaruhinya yaitu: kematian, kelahiran dan perpindahan penduduk.

\section{Pembahasan}

\section{Latar Belakang Kehidupan Nelayan Di Kelurahan Lonrae}

Letak dan kondisi geografis suatu daerah sangat mempengaruhi mata pencaharian masyarakat yang mendiami daerah tersebut. Dengan demikian keadaan alam merupakan salah satu faktor penunjang bagi kehidupan masyarakat dalam pemenuhan kebutuhan hidupnya. Misalnya masyarakat yang bermukim di wilayah pesisir pantai memanfaatkan potensi biota laut kemudian diolah agar mampu menunjang kebutuhan sehariharinya. (Kusnadi 2003)

Kelurahan Lonrae terletak di pesisir pantai, dalam hal ini laut sebagai tempat pemenuhan kebutuhan dan kelangsungan hidup dengan melakukan penangkapan ikan. Karena sebagai nelayan mereka bergantungan pada sumber daya alam yang ada dilautan. Selain itu juga faktor mengapa masyarakat beralih kelautan karena melihat kondisi tanah yang tandus dan bebatuan sehingga tidak memungkinkan untuk melakukan usaha pertanian.

Dengan demikian keadaan lingkungan merupakan faktor yang sangat berpengaruh dalam kehidupan masyarakat. keadaan geografis Kelurahan Lonrae terhadap potensi sumber daya lautnya turut menentukan kehidupan masyarakatnya yang bermata pencaharian sebagai nelayan.

Masyarakat pesisir nelayan Lonrae sebagian besar berprofesi sebagai nelayan yang mereka peroleh secara turun temurun dari nenek moyang mereka dan tidak diketahui secara pasti kapan masyarakat disana memulai melakukan penangkapan ikan dilaut sebagai sumber penghidupan masyarakat pesisir.

\section{Pola Kegiatan Nelayan di Kelurahan Lonrae \\ Pola kegiatan nelayan di Kelurahan} Lonrae tahun 1970-an belum mengalami perkembangan dan perubahan hal ini dapat dilihat pada pola penangkapan, pola pemasaran (distribusi), pola pengolahan hasil tangkapan serta sarana dan peralatan yang masih sederhana.

\section{a. Pola Penangkapan Ikan}

Sebelum adanya perkembangan nelayan di Kelurahan Lonrae dalam kegiatan penangkapan ikan di sekitar pinggiran pantai saja. Hal ini disebabkan karena nelayan masih menggunakan perahu dengan bantuan dayung dan layar. Selain itu nelayan masih menggunakan alat tangkap yang berupa pancing tabiri sehingga jangkauan penangkapan ikan hanya sekitar satu sampai dua mil saja.

Kemudian Setelah memasuki tahun 1975 barulah terjadi pembaharuan masyarakat di wilayah pesisir dari pemesinan perahu dan alat tangkap yang kian berkembang dengan demikian jangkauan penangkapan ikan lebih jauh dan mempersingkat waktu dalam proses penangkapan ikan dilaut dan penerangan lampu yang digunakan pun masih belum memadai

Kemudian memasuki tahun 1990 sampai 2017 terjadinya perkembangan dalam proses penangkapan ikan pada waktu malam dengan menggunakan penerangan lampu strongken sehingga dimanfaatkan untuk memaksimalkan produktivitas penangkapan ikan bagi nelayan di Kelurahan Lonrae. Dimana masyarakat nelayan di Kelurahan Lonrae bermalam dilautan. Wilayah penangkapan ikan pun cukup jauh. Selain itu juga mereka ditunjang dengan perahu yang ukurannya lebih besar.

\section{b. Pola Pemasaran}

Volume 6 No.2 April-Juni 2019, 65-77 |71 
Kemudian Pada tahun 1975 ikan yang dipasarkan masih dalam keadaan yang masih sangat segar karena pada fase ini kalangan masyarakat nelayan belum mengenal sistem pengawetan ikan dengan menggunakan es selain itu jaringan pemasaran belum terlalu luas karena hanya meliputi pasar yang berada di Kelurahan Lonrae yaitu "Pasar bajoe".

Kemudian tahap selanjutnya adalah masyarakat mengenal sistem pengawetan ikan dengan menggunakan es pada tahun 2000 sehingga tahap semakin berkembang hal ini ditandai dengan hadirnya pabrik es milik seorang perusahaan cina yang bernama "Pameng menciong". Kemudian ikan dari hasil tangkapan tersebut di kelompokkan berdasarkan jenis ikan dan digabungkan dalam sebuah wadah kemudian tahap berikutnya adalah tahap pemasaran, kemudian tahap selanjutnya adalah tahap pengawetan dengan menggunakan es yang telah dihancurkan untuk mempermudah proses penaburan di atas ikan agar kualitas ikan tidak mudah rusak dan bisa menurunkan harga ikan tersebut. (Amirullah 2017)

Tahap selanjutnya adalah tahap pengangkutan ikan ke beberapa pasar yang ada di Kabupaten Bone, Seperti: Pasar bajoe, Pasar Palakka, Pasar Sentral dan beberapa daerah lainnya dengan angkutan menggunakan mobil Pick Up.

Kemudian tahun 2005 sampai 2017 proses pemasaran tidak hanya dipasar lokal yang ada di Kabupaten Bone itu saja akan tetapi sudah sampai di Kabupaten Soppeng dan Sinjai. Selain itu juga terdapat pola pemasaran yaitu para nelayan yang kembali dari penangkapan ikan langsung menjual hasil tangkapannya ke pedagang atau pengecer, jadi tidak melalui pelelangan. terkhusus untuk tangkapan nelayan yang memperoleh ikan tuna yang tidak dipasarkan di Kabupaten bone akan tetapi di bawah ke makassar karena ikan tuna memiliki kualitas tinggi dalam nilai jual dibandingkan dengan jenis ikan yang lainnya.

\section{c. Pola Pengolahan Hasil Produksi}

Pada tahun 1975 sampai 1990 Pengolahan hasil tangkapan dilakukan masyarakat nelayan lonrae belum mengenal pengawetan ikan yang berbahan dasar es sehingga garam adalah bahan alternatif yang digunakan. Selain menggandalkan garam, hal yang tidak kalah pentingnya adalah panas matahari untuk mengeringkan ikan yang telah diasingkan. Tempat yang dijadikan untuk menjemur hasil produksi kadang kala di halaman rumah.

Adapun hasil olahan yang diperoleh seperti: Ikan Asing dengan proses pengasingan ikan dapat dilakukan pada tempat yang luas. Selain itu ikan yang diolah adalah ikan yang mulai mengalami penurunan kualitas akibat keterlambatan para nelayan sampai ke daratan akibat cuaca buruk dan hanya mengandalkan tenaga layar dan dayung.

Hasil olahan selanjutnya adalah ikan asap (Bale' tafa) yang diolah dengan proses pengasapan di atas bara api. Dari keadaan tersebut mendorong lahirnya usaha rumah tangga tahun 2005 dan masih ada tetap sampai sekarng (saat penelitian) sebagai pedagang Bale'Tafa (Ikan Asap) dan masih ada tetap sampai sekarng (saat penelitian) dan salah satu pedagang ikan yang telah berhasil adalah $\mathrm{Hj}$. Sitti. Hasil olahan tersebut mendapatkan banyak peminat baik dari daerah yang tidak berpantai dan bukan penghasil ikan. Kemudian dipasarkan secara lokal di pasar yang ada di Kabupaten Bone. (Sitti 2019)

\section{d. Sistem Bagi Hasil}

Pola penangkapan ikan yang dilakukan secara berkelompok berdasarkan kekeluargaan sehingga sistem bagi hasil tidak terlampau jauh perbandingannya antara yang satu dengan yang lainnya. Sistem bagi hasil didasrkan pada 
kepemilikan perahu, alat tangkap dan keikutsertaan melaut. Adapun sistem bagi hasilnya dapat diuraikan sebagai berikut:

1). Punggawa Lompo (Punggawa): 3 bagian

2). Punggawa Lopi : 2 bagian

3). Sawi

: 1 bagian $(\mathrm{H}$. Bustan

2019).

\section{Perkembangan Nelayan di Kelurahan Lonrae}

a. Perkembangan Jenis Perahu Nelayan Lonrae

1) Perahu Pande'

Perahu digunakan oleh nelayan di

Kelurahan Lonrae untuk menangkap ikan walaupun hanya di pinggir pantai. Perahu Pande" tidak menggunakan layar hanya dengan bantuan dayung sebagai alat penggerak dari perahu tersebut. Perahu ini hampir sama dengan Sampan. Pande" ini hanya muat dengan kapasitas 2 orang. Perahu Pande' ini marak digunakan pada tahun 1960an oleh nelayan di Kelurahan Lonrae. Adapun jenis ikan yang hasilkan masih kecil-kecil: Ikan Bini-bini. Nelayan di Kelurahan Lonrae belum menangkap ikan dalam ukuran besar seperti: ikan Tuna, (Baby tuna) layang, dan cakalag karena proses penangkapan ikan masih di daerah pedalam yang rendah.

Kemudian pola penangkapan ikan nelayan di Kelurahan Lonrae masih bersifat individual belum tercipta kelompok kerja pada masa itu hal ini menimbulkan orientasi ekonomi nelayan di Kelurahan Lonrae masih bersifat subsistensi dan belum beriorentasi pasar (Ahmadin, 2009; Najering, 2018; Rifal \& Sunarti, 2018).

Perahu jenis Pande' tersebut sekarang jumlahnya sudah sangat minim dan langka sekali. Karena nelayan di Kelurahan Lonrae hanya menggunakan perahu jika ada selingan waktu saja karena menggunakan perahu pande' ini hanya digunakan menangkap ikan di perairan dangkal saja. (Lukman 2019).

\section{2) Perahu Soppek}

Perahu Soppek adalah jenis perahu alat tangkap nelayan yang digunakan pada tahun 1975 sampai 1990 yang awalnya diperkenalkan oleh "Jaggo Sakki" yang merupakan orang mandar sehingga pada saat itu ada beberapa orang yang menggunakan perahu tersebut. Ukuran dari perahu ini lebih besar dari Perahu Pande' dan jarak penangkapan ikan lebih jauh. Perahu ini terbuat dari bambu yang terdiri atas dua sisi kanan kiri yang digunakan sebagai alat penyeimbang sehingga perahu tidak mudah tenggelam. Dengan panjang sekitar tiga atau empat panjangnya, dan lebarnya berkisar dua meter dan tingginya dua meter selain itu juga perahu ini sudah menggunakan alat bantu penggerak dengan layar (H. Side 2019).

Dengan adanya perahu soppek tersebut waktu tempuh dalam perjalanan penangkapan ikan pun tak membutuhkan waktu lama lagi bahkan wilayah jangkauan dalam penangkapan ikan pun sudah mulai agak jauh. Maka dengan ini masyarakat nelayan lonrae lambat laun sudah mengalami perkembangan karena mereka sudah menggunakan layar sebagai alat bantu dalam penangkapan ikan dilaut. Adapun yang masih memiliki perahu soppek sebagai berikut. Akan tetapi perahu soppek di Kelurahan Lonrae sudah langka dan jarang yang menggunakannya karena di pengaruhi dengan penemuan baru jenis perahu yang lebih modern lagi (Baso 2019).

\section{3) Perahu Motor Merk Katingting}

Perahu katingting adalah jenis perahu alat tangkap nelayan yang digunakan pada tahun 1990 sampai 2017, Perahu Katinting ini berkisar panjangnya empat belas meter, lebar empat meter dan tingginya dua meter. Perahu Ketinting ini dibuat oleh Orang Bulukumba yang bernama Masmur yang datang di Kelurahan Lonrae. Selain itu juga Perahu Katinting ini hadir setelah motorisasi perahu nelayan pada tahun 1975 
dengan mesin katinting dengan $5 \mathrm{Pk}$ (Darwis 2019).

Dengan hadirnya Perahu jenis Katingting ini maka proses jangkauan nelayan dalam proses penangkapan ikan sudah semakin jauh di daerah Sulawesi Tenggara seperti: Kendari dan Kolaka. Sehingga waktu melaut nelayan lonrae itu berkisar 3-7 hari lamanya. Selain ukuran dari Perahu katingting ini memiliki tempat penampungan ikan yang lebih besar sehingga bisa menampung ikan karena nelayan sudah membawa balok es untuk pengawetan ikan sehingga ikan yang ditangkap tidak akan rusak (H. Side 2019).

Perahu jenis Perahu Katinting ini yang kemudian berkembang sampai sekarang (Saat penelitian) yang banyak digunakan nelayan di Kelurahan Lonrae karena selain dari segi besarnya juga dilengkapi dengan bak penampungan ikan yang bisa mengawetkan sampai berhari-hari.

\section{b. Perkembangan Alat Tangkap}

Kegiatan penangkapan ikan merupakan pekerjaan yang sangat sulit dan berat bagi para nelayan karena mereka harus mengarungi lautan, menghadapi ombak dan badai ditengah laut yang setiap saat dapat mengancam keselamatan hidup mereka, karena mereka menggantungkan kelangsung hidupnya dari wilayah pesisir dan mengelola sumber daya alam yang tersedia di lingkungannya, yakni di Perairan laut (R. Alimuddin 2004).

Pada penangkapan ikan di Kelurahan Lonrae sampai sekarang sudah mengalami perkembangan dan perubahan, dapat lihat dari perkembangan penggunaan alat tangkap yang digunakan. Hal ini disebabkan karena lahirnya terbuka dan pola pikir masyarakat nelayan di Kelurahan Lonrae untuk berkembang kearah yang lebih maju

Pada tahun 1975 pengkapan ikan di Kelurahan Lonrae mengalami perubahan diperkenalkan oleh Suku Mandar yang bernama Mile yang melaut sampai ke Pantai Lonrae yang dikenal dengan "Pancing Tabiri". Pancing Tabiri adalah alat penangkapan yng digunakan pada kedalaman mencapai ratusan meter karena ikan yang ditangkap adalah jenis ikan yang sering berada di atas permukaan air seperti: Ikan layang yang ukuranya tidak terlalu besar. Sistem kerja jenis alat tangkap ini menggunakan mata pancing sampai ratusan sehingga daya tangkapnya pun semakin banyak dari sebelumnya tunggal, setiap mata di berikan umpang ikan tetapi dengan menggunakan kain berwarna-warni sehingga kelihatannya lebih indah jika dibawah laut menarik perhatian para ikan-ikan (Tike, Perkembangan Alat Pancing 2019).

Dari keterangan di atas menjelaskan bahwa Pancing Tabiri' masih di gunakan sampai sekarang oleh para masyarakat nelayan di Kelurahann Lonrae. Kemudian lambat laun di temukan alat tangkap yaitu: "Panci Panoi" pada tahun 1990 oleh salah seorang nelayan Suku Mandar yang bernama H. Tike. Pancing Panoi' menggunakan Pancing yang berukuran besar yang berbahan dasar kain berwarna sehingga memperoleh ikan yang besar.

Pancing Panoi" dalam bahasa bugis" menurunkan" jadi dikaitkan dengan kegiatan nelayan lonrae adalah menurunkan pancing di dalam air dengan menggunakan alat pemberat sehingga bisa mencapai ikan yang berada di kedalam sampai di dasar laut yang tidak bisa di jangkau oleh Pancing Tabiri. akan tetapi perkmbangan alat tangkap nelayan tidak sampai disini malahan mengalami perkembangan yang ditandai dengan penemuan alat tangkap pada tahun 2000 sampai 2017 yaitu "Pancing Rudal" yang berbahan kain yang berwarna tetapi menggunakan pintil sebagai penghias pancing dan berada di dalam air yang menarik perhatian ikan.

Volume 6 No.2 April-Juni 2019, 65-77 |74 
Pancing Rudal ini digunakan pada Rompong. Rompong adalah tempat ikanikan kecil yang memakan lumut-lumut yang menempel. Pancing Rudal ini adalah alat tangkap yang digunakan untuk menangkap ikan tuna karena terdapat banyak kecil yang bisa di mangsa. Rompong ini pertama kali diperkenalkan oleh Suku Mandar yang Bernama "Jakko Sakki" Pembuatan Rompong tersebut dilakukan secara gotong royong oleh para nelayan seperti pengambilan batu sebagai pemberat, bambu sebagai pelampung dan daun kelapa sebagai tempat menempelnya lumut sebagai makan ikan.

\section{Dampak Nelayan Terhadap Masyarakat Sekitar \\ a. Bidang Sosial}

Penggunaan teknologi modern dalam usaha penangkapan ikan telah membawa perubahan yang berarti dalam kehidupan sosial masyarakat nelayan di Kelurahan Lonrae. Perubahan-perubahan tersebut tergambar pada status sosial dan stratifikasi sosial serta perubahan pola hidup yang tidak terlepas dari kehidupan ekonomi masyarakat setempat. Status sosial bagi masyarakat nelayan di kelurahan lonra tidak lagi diukur berdasarakan tingkat keturunannya (bangsawan atau tidak) tetapi dari seberapa jauh ia mampu bersaing dalam kehidupan dan kemampuan ekonomi dengan masyarakat nelayan lainnya.

Status sosial nelayan di kelurahan lonrae diperoleh bila seseorang dianggap memiliki kelebihan-kelebihan dari sesama lainnya, seperti: status haji, pemilikan perahu bermotor, pemilikan kendaraan, dan kepemilikan rumah dan isinya. Masyarakat di kelurahan lonrae berada pada lapisan atas jika memiliki kekuatan secara ekonomi. Stratifikasi sosial dalam masyarakat lonrae berdasarkan terbagi atas tiga golongan yaitu: pemilik Kapal (Juragan), Punggawa ( Mengorganisir anggotanya), menyiapkan modal, memasarkan hasil produksi ikan), dan Sawi. Punggawa sebagai golongan masyarakat yang berada pada lapisan atas bukan hanya sebagai pemimpin kapal, melainkan juga selaku penolong bagi sawi dalam mengatasi masalah ekonomi yang dihadapinya. Dengan adanya penggunaan teknologi modern bagi masyarakat nelayan lonrae itu dapat memberikan kesejahteraan hidup.

Bahkan para nelayan dapat menyekolahkan anak-anak mereka sampai ke perguruan tinggi karena mereka beranggapan bahwa orang tuanya tidak ingin melihat anaknya menggeluti pekerjaan sebagai seorang nelayan. Dengan harapan kelak anaknya bisa menjadi seorang pegawai negeri sipil seperti: TNI, POLRI hal ini harapan agar derajat keluarga menjadi terpandang dikalangan masyarakat. keadaan ini juga memberikan perubahan dalam struktur sosial karena orang yang memiliki pendidikan tinggi lebih dihormati dibandingkan masyarakat pada umunya.

\section{b. Bidang Ekonomi}

Dengan adanya perkembangan teknologi pengetahuan dalam bidang perikanan memberikan peningkatan hasil produksi tangkapan yang dicapai sehingga mampu meningkatkan pendapatan nelayan. Kondisi ini kemudian mengalami perubahan dari waktu ke waktu seiring dengan perkembangan teknologi dan peningkatan hasil tangkap setelah masuknya teknologi modern. Peningkatan ekonomi masyarakat nelayan yang ditunjukkan dengan semakin membaiknya kondisi fisik rumah tempat tinggal rata-rata penduduk nelayan Kelurahan Lonrae.

Peningkatan taraf ekonomi masyarakat nelayan Kelurahan di Kelurahan Lonrae juga dapat diukur dari perabot serta perlengkapan rumah tangga yang dimiliki oleh setiap keluarga nelayan. Peningkatan taraf ekonomi dapat dilihat dalam

Volume 6 No.2 April-Juni 2019, 65-77 |75 
penggunaan perabot rumah tangga seperti: TV, Kulkas, rice cooker, kipas angin dan sebagainya. Dan juga sudah memiliki barang mewah. Seperti: motor yang telah banyak dimiliki oleh masyarakat nelayan lonrae

\section{c. Bidang Budaya}

Nelayan sebagai salah satu unsur masyarakat mempunyai budaya yang telah tumbuh dan mengakar dalam diri dan kehidupan masyarakat pada masanya. Budaya tersebut terwujud dalam tradisi, kebiasaan dan pamali yang dilakukan sangat erat kaitannya dengan kepercayaan dan pengetahuan yang miliki oleh para nelayan. Sama halnya dengan kehidupan nelayan lonrae memiliki tradisi dan pamali yang dilakukan sebelum melakukan aktivitas melaut.

Sebelum melaut para nelayan dianjurkan secara kultur untuk melakukan pengamatan terhadap simbol-simbol tertentu dari alam, dengan pertimbangan bahwa demi keselamatan diri serta untuk memprediksi ada atau tidaknya hasil tangkapan yang akan diperoleh. Hal ini tentu saja didasarkan atas beberapa pengalaman sebelumnya, bahwa ada diantara mereka yang mendapat kecelakaan karena tidak menghiraukan pesan ini (Ahmadin 2009).

Berdasarkan tradisi yang dilakukan oleh masyarakat nelayan lonrae tersebut sangat dijunjung tinggi pada era tahun 1970an akan tetapi dengan seiring perkembangan ilmu pengetahuan dan teknologi melahirkan teknik-teknik baru dan pandangan baru yang demikian itu akan melemahkan keyakinan mereka akan ha-hal yang berbau sakral dan tidak rasional, dengan demikian menyebabkan tradisi tradisi tradisional tersebut sudah semakin jarang dilaksanakan, hanya sebagian kecil diantara mereka yang masih mempertahkannya

\section{E. Kesimpulan}

Sebelum nelayan di Kelurahan Lonrae mengalami perubahan maka pola kegiatan produksi atau kegiatan menangkapnya tidak jauh dari garis pantai karena keterbatasan yang dialami dan masih bersifat tardisional. Masyarakat pesisir masih mengandalkan perahu yang ukurannya kecil sehingga volume tangkapannya masih kecil. Dengan adanya perubahan dan modifikasi alat tangkap pancing pada nelayan membawa perubahan pada pola produksi atau terjadinya perubahan volume tangkap yang meningkat sehingga terjadi peningkatan taraf hidup.

Perkembangan yang terjadi tidak hanya pada alat tangkap utama seperti pancing tetapi juga terjadi pada perahu yang digunakan juga beberapa kali mengalami perubahan, mulai dari penggunaan perahu pande pada tahun 1960an dan kemudian berubah menjadi soppek pada tahun 1975 yang dibuat oleh seorang tukang dari Bulukumba yang bernama H. Ambo Sakki dan sampai penggunaan perahu motor dengan Merk Katinting yang bertahan sampai sekarang (saat penelitian).

Kemudian Setelah terjadinya perkembangan pada nelayan di Kelurahan Lonrae maka berdampak pada kegiatan ekonomi yaitu dengan lahirnya usaha rumah tangga seperti pedagangan ikan asap dan pedagang ikan kering sebagai bentuk pengolahan hasil produksi atau hasil tangkapan nelayan yang diolah dalam berbagai bentuk yang berbeda-beda dan dipasarkan pada daerah di Kabupaten bone. Pada bidang sosial pun terjadi perubahan karena terciptanya kedudukan sosial berdasarkan tingkatan ekonomi dan begitu pun dalam bidang budaya seiring perkembangan ilmu pengetahuan dan teknologi melahirkan teknik-teknik baru dan pandangan baru yang demikian itu akan melemahkan keyakinan mereka akan ha-hal yang berbau sakral dan tidak rasional, dengan demikian menyebabkan

Volume 6 No.2 April-Juni 2019, 65-77 |76 
tradisi tradisi tradisional tersebut sudah semakin jarang dilaksanakan, hanya sebagian kecil diantara mereka yang masih mempertahkannya.

\section{F. Daftar Pustaka}

Abdulgani, Roeslan. Penggunaan Ilmu Sejarah. Bandung: Prapanntja, 1963.

Abdullah, Hamid. Manusia Bugis Makassar. Jakarta: Inti Indayu Pres, 1985.

Abdullah, Taufik, dan (Eds) Adrian Lapian. Indonesia Dalam Arus Sejarah Jilid 8. Jakarta: Ichtiar Baru Van Hoeve, 2012.

Ahmadin. Makassar: Rayhan Intermedia, 2009.

-. Makassar: Rayhan Intermedia, 2009.

-. ketika Lautku Tak Berikan Lagi. Makassar: Rayhan Intermedia, 2009.

-. Metode Penelitian Sosial. Makassar: Rayhan Intermedia, 2013.

-. Nelayan Tradisional dan Modernisasi: Potret Masyarakat Pesisir di Pulau Selayar. Makassar: Rayhan Intermedia, 2009.

Ahmadin. Metode PenelitianSosial. Makassar: Rayhan Intermedia, 2013.

Akisman. Dampak keberadaan Bendung Awo (Oktober 6, 2017).

Alimuddin, M Ridwan. Mengapa Kita Belum Cinta Laut. Yogyakarta: Ombak, 2004.

Alimuddin, Muhammad Ridwan. Mengapa Kita Belum Cinta Laut. Yogyakarta : Ombak, 2004.

Alimuddin, Ridwan. Mengapa Kita Belum Cinta Laut. Yogyakarta: Ombak, 2004.

Amirullah. "KOMUNITAS NELAYAN LAGGOPPO DI KABUPATEN BONE (1972-2010)." Jurnal Pattingalloang, 2017: 1-10.

Andaya, Y, Leonard. Warisan arung Pallakka, Sejarah Sulawesi selatan abad ke 17. Makassar: Inninnawa, 2013.
Andi, Muljadi dan Warman. Pariwisata dan Perjalanan. Jakarta: Rajawali Pers, 2016

April. (n.d.).

Arafiky, Rezky. Tradisi Pattaungeng di Situs Bulu Matanre Desa Mattabulu Kecamatan Lalabata Kabupaten Soppeng (1990-2015). Makassar: Fakultas Ilmu Sosial Universitas Negeri Makassar, 2017.

Arfah Muhammad, dkk. Sejarah Perjuangan Bangsa di Daerah Sulawesi Selatan. Ujung Pandang: Departemen pendidikan dan Kebudayaan, 1995.

Arfah, Muhammad, dkk. Haji Andi Mappanyukki Biografi Pahlawan Haji Andi Mappanyukki, Sultan Ibrahim Profil Nasionalis dan Patriotik Sejati Yang konsekuen terhadap Republi. Ujung Pandang: Departemen Pendidikan dan kebudayaan., 1993.

Arief, Aburaera. Kamus Makassar Indonesia. Ujung Pandang: Kapita DDI Ujung Pandang, 1995.

Arif, Sabr. PDAM Makassar (maret 5, 5 Maret 2018).

Arifin, Bustanul. Analisis Ekonomi Prtanian Indonesia. Jakarta: Kanisus, 2004.

Arifuddin Ismail. Agama Nelayan. Yogyakarta: Pustaka Pelajar, 2012.

Arsip Pribadi Muhammad Saleh Lahade No. Reg 191. No. Reg 191. Makassar: Badan Perpustakaan dan Kearsipan Sulawesi Selatan, 1937-1973.

Arsyad, Muh. Wawancara di Malino (Maret 23, 2018).

Asse, Ambo. Latarbelakang terjadi perubahan pola pertanian (Maret 8, 2018).

Volume 6 No.2 April-Juni 2019, 65-77 |77 